\title{
O092: Clean hands: an university extension project
}

\author{
AFV Tipple*, JLU Spagnoli, ZCP Neves, JEM Santos, FCR Cesar, JPDA Trindade, KCDO Batista \\ From 2nd International Conference on Prevention and Infection Control (ICPIC 2013) \\ Geneva, Switzerland. 25-28 June 2013
}

This video presents the story of a university extension project called "Clean Hands" which originated from a master's dissertation in 2006, based at the Center for Studies and Nursing Research for the Prevention and Control of Healthcare Associated Infections (NEPIH) based at the Center for Studies and Nursing Research for the Prevention and Control of Healthcare Associated Infections (NEPIH) at the School of Nursing, Federal University of Goiás, Brazil, and is registered with the Pro-Chancellor of Extension at the university. Since its creation, the project has developed activities to encourage the establishment of hand hygiene $(\mathrm{HH})$ in health care, in cooperation with professionals, academics, patients and caregivers, as well as in scientific events, with academics and health professionals. After the outbreak of H1N1 in 2009, the project developed campaigns in municipal daycare centers (CMEI), the Municipal Department of Education, of the city of Goiânia, Goiás, Brazil, targeting children, parents and workers. In these campaigns, different promotion strategies are used: informative stylized banners depicting $\mathrm{HH}$; educational brochures, a song parody $\mathrm{CD}$, demonstration of proper $\mathrm{HH}$ technique, using poster paints on children's hands; a puppet theater; and face-to-face discussions about the importance of, obstacles to, and benefits of $\mathrm{HH}$. Annually, the project hosts a festival of parodies with the theme of $\mathrm{HH}$, called "CANTA FEN", which brings together academics and healthcare professionals. The project's day-to-day operations are normally run by five students, supported by the other members of NEPIH, currently 33 staff members (faculty, undergraduate and graduate), participating in the activities of the project. Up to February 2013, the project has performed about 180 campaigns ( 45 were for children) reaching approximately 8,000 people. Participation in the project has contributed to the development of skills and

Faculdade de Enfermagem, Universidade Federal de Goiás, Goiânia, Brazil competencies with regard to the implementation of health promotion strategies with different audiences and requires that students constantly stay up to date on the subject. The festival of parodies has helped to empower its members to conduct scientific and cultural events and promote emphasis of the subject in a playful manner.

\section{Disclosure of interest}

None declared.

Published: 20 June 2013

doi:10.1186/2047-2994-2-S1-092

Cite this article as: Tipple et al:: O092: Clean hands: an university extension project. Antimicrobial Resistance and Infection Control 2013 2(Suppl 1):092.
Submit your next manuscript to BioMed Central and take full advantage of:

- Convenient online submission

- Thorough peer review

- No space constraints or color figure charges

- Immediate publication on acceptance

- Inclusion in PubMed, CAS, Scopus and Google Scholar

- Research which is freely available for redistribution
() Bïomed Central
(C) 2013 Tipple et al; licensee BioMed Central Ltd. This is an Open Access article distributed under the terms of the Creative Commons Attribution License (http://creativecommons.org/licenses/by/2.0), which permits unrestricted use, distribution, and reproduction in any medium, provided the original work is properly cited. 